\title{
Problems of security
}

\section{Washington}

WHEN a computer 'virus', written by Cornell University graduate student Robert Morris, traversed the Internet electronic-mail network to infect thousands of host computers (see Nature 336, 97; 1988), the immediate flaws in the system which permitted the tainted program's easy transmission were quickly remedied, and no permanent damage was caused. But the incident exposed general weaknesses in the security of computer networks, which the General Accounting Office (GAO), an investigative arm of the US Congress, sets out in a report issued last week. And at a hearing in Congress last week, some remedies were proposed which may alarm computer users more than the virus threat itself.

The GAO report highlights two problems: lax security at academic computer installations and a lack of established legal principles by which network intruders can be prosecuted. In the aftermath of last year's virus infection, computer managers and users have become more safetyminded (see Nature 336, 301; 1988), and a number of bills now being considered in Congress have provisions to extend definitions of fraud and property so as to encompass computer-security violations. But GAO goes further and recommends the establishment of a central body, under the umbrella of the White House Office of Science and Technology Policy, which would oversee security policy and take a hand in network management.

No detailed proposal is made, but the idea that changes in a local operating system, for example, would have to be submitted to a central body for scrutiny

\section{SATELLITES}

\section{Hipparcos launch delay}

\section{London}

AN electrical storm has delayed the launch of the Hipparcos, the European Space Agency (ESA)'s astrometry satellite, originally scheduled for 27 July (see Nature 340; 111-116, 1989). According to project director Michael Perryman, the problem stemmed not from Hipparcos but from the television satellite TVSAT-2, which shares an Ariane-4 rocket with Hipparcos. The storm broke when TVSAT-2 was powered up for electrical tests, and extra time was needed for additional tests to check for storm damage. All systems now appear to be in working order, and the mission will now blast off from the ESA Space Centre in Kourou, French Guiana, on 8 August. The TVSAT series has been dogged by problems: TVSAT-1 was launched successfully, but was effectively rendered useless because its solar panels failed to deploy. Henry Gee and approval would not sit well with the free-thinking ethos of university computer departments.

Jim Conklin of EDUCOM, an organization that studies information and communications issues for the academic community, agrees that a combination of technical and legal action is needed to guard against future virus attacks, but warns against measures that would "kill the network" in fighting the "occasional glitch".

Although the GAO report makes the criticism that many individuals who discovered the virus had no idea to whom they should report the problem, the quick preventive action against the intrusion was in part due to network users who wrote and distributed anti-viral program patches without bothering to consult any higher authority. Over-elaborate security policies and reporting procedures, says Conklin, may stifle this kind of rapid but improvised response.

Many computer users who had cheered security violations, such as the break-in by a West German amateur into a system at Lawrence Berkeley Laboratory (see Nature 333, 105; 1988), as praiseworthy examples of the 'hacker' mentality changed their minds when Morris's virus threatened their own filespace. Conklin sees this change as part of a needed institutional response. The other ingredient is the creation of new legal principles, but this may not be easy. The Federal Bureau of Investigation (FBI) made little attempt to investigate the Berkeley breach: no data were stolen and no programs were destroyed, and the FBI could find no firm grounds for prosecution.

The kind of legal measures suggested by GAO and, at a House Energy and Commerce subcommittee hearing last Thursday, by John Landry of ADAPSO, a computer software and services industry association, would rely on new definitions of unauthorized access and damage to computers, so that the perpetrator of a virus which merely slowed down operations without erasing data or programs would be prosecutable. But does the spread of a virus on an open electronic mail network constitute 'unauthorized access'? And is a program that browses through a database, perhaps copying parts of it, engaged in an act of theft? The technicality of the concepts involved has discouraged tests of existing laws which might address these questions, and makes it hard to draw up sound new laws. The best that can be huped for, according to Conklin, is that network security and legal safeguards will at least keep pace with the threats; those who operate and use the networks are as ingenious as those who would infiltrate them.

\section{Youth plan takes shape}

Munich

THERE can never be enough money for university research; this maxim was demonstrated once again last week by the influential West German science council Wissenschaftsrat, which greeted enthusiastically a plan to invest DM6,000 million (about $\$ 3,150$ million) over ten years to keep young researchers at universities. Mouths watered in universities all over West Germany in May when Education Minister Jürgen Möllemann (Free Democrat) announced the plan, the purpose of which is to prepare for an expected wave of retirements of university professors in the years 1995 to 2005 .

The council made clear, however, that the best students can be persuaded to stay at university only if there is sufficient support for their research. So the granting agency DFG (Deutsche Forschungsgemeinschaft) should receive the secondlargest share of the money after the universities themselves. DFG spokeswoman EvaMaria Streier said that DFG would plough virtually all the money into its normal granting programmes.

Streier also said that DFG supports the council's plan to encourage more women to enter science by providing special scholarships and encouraging flexibility in career planning. Figures distributed in early July by the Federal Statistics Office in Wiesbaden underscore the need for more women in academic pursuits. Although about 40 per cent of the students at West German universities are women, only 5.1 per cent of professors are women.

The council also called for extending the so-called Fiebiger programme until about 1995. This programme gives short-term positions to young researchers until professorships become available.

An official at the Research Ministry (BMFT) sees similar problems in government research establishments such as the Max Planck Institutes and the so-called Large Research Establishments. He welcomed the programme and suggested taking advantage of the capacity of such research institutions to employ graduate students and other young researchers until there are jobs available for them in universities.

At present, many of the best students do not even apply for stipends for postgraduate research because industry can offer them more money, said Wilhelm Krull of Wissenschaftsrat.

The heads of science organizations in West Germany eagerly await a meeting on 21 September with Möllemann, Research Minister Heinz Riesenhuber, Chancellor Helmut Kohl and the heads of the Länder (states), when a decision is expected about the size of the programme. Until then, researchers remain sceptical about whether there will be as much money as Möllemann has promised. 